\title{
Distribution of style and pollen polygalacturonases among distylous and homostylous Turnera and Piriqueta spp. (Turneraceae)
}

\author{
F Tamari and JS Shore \\ Department of Biology, York University, 4700 Keele Street, Toronto, Ontario, Canada M3J 1P3
}

\begin{abstract}
We explore the distribution of a style and pollen polygalacturonase in a number of distylous and homostylous species of Turnera, and two species of Piriqueta (Turneraceae). We show, using immunoblotting with antibodies made against these proteins, that the style polygalacturonase is specific to styles of short-styled plants of all the six distylous species of Turnera we have investigated. Styles of a somatic homostylous mutant derived from a short-styled plant do not possess the style polygalacturonase. Distylous $P$. caroliniana did not appear to possess this protein. We show that the pollen polygalacturonase, while associated with the shortstyled morph in three species, is polymorphic among shortstyled plants of $T$. krapovickasii, and absent from T. joelii,
\end{abstract}

T. grandiflora and $P$. caroliniana. These data support a role for the style polygalacturonase in distyly, possibly in the incompatibility system, but cast doubt on any role for the pollen polygalacturonase. In concert with the predictions for the mode of origin, and the response of styles of homostylous species to pollen from long- and short-styled plants, we find that none of the homostylous species possess the style polygalacturonase. The pollen polygalacturonase does occur in some homostylous species, but not in others. It is not clear that the pollen polygalacturonase, however, provides a marker for the mode of origin of homostyly.

Heredity (2004) 92, 380-385, advance online publication, 3 March 2004; doi:10.1038/sj.hdy.6800390

Keywords: distyly; homostyly; Turnera; polygalacturonase; immunoblotting

\section{Introduction}

While distyly has provided a useful model system in ecological genetics, a clear understanding of the genes / proteins involved and the mechanisms of incompatibility have yet to be determined. There have been no convincing demonstrations of the occurrence of selfincompatibility proteins in any heterostylous species, although some efforts have been made in this direction (Golynskaya et al, 1976; Shivanna et al, 1981; Wong et al, 1994; Athanasiou and Shore, 1997). Turnera spp provide a useful system for identifying genes and proteins involved in distyly and self-incompatibility, given the relative ease and speed with which plants may be crossed and brought to flowering, and the increasing amount of work on distyly in this genus (Shore and Barrett, 1985; Barrett and Shore, 1987; Athanasiou and Shore, 1997; Tamari et al, 2001; Athanasiou et al, 2003). Distyly in Turnera scabra and T. subulata is determined by a single diallelic locus, where short-styled plants are heterozygous, Ss, and long-styled plants are homozygous, ss (Shore and Barrett, 1985). Pollen tube studies reveal that there is an asymmetry in the sites of selfincompatibility among the morphs. Self pollen tubes of short-styled plants germinate and penetrate the stigma, rarely enter the style and do not possess callose plugs, while self pollen tubes of long-styled plants tend to

Correspondence: JS Shore. Department of Biology, York University, 4700 Keele Street, Toronto, Ontario, Canada M3J 1P3. E-mail: shore@yorku.ca Received: 18 October 2002; accepted: 13 September 2003; published online 3 March 2004 penetrate further into the style, and do possess callose plugs (Tamari et al, 2001). Tamari et al (2001) suggested that this asymmetry could indicate that the morphs possess different self-incompatibility mechanisms.

Athanasiou and Shore (1997) and Athanasiou et al (2003) provided evidence that proteins specific to the styles and pollen of short-styled plants of distylous Turnera scabra and T. subulata might be involved in distyly, possibly in the incompatibility system. Athanasiou et al (2003) showed that both proteins are polygalacturonases and that the style polygalacturonase is localized to the style-transmitting and stigmatic tissue. Furthermore, they showed that the style polygalacturonase was linked to, and approximately $4.6 \mathrm{cM}$ distal to, the distyly locus. The map location of the pollen polygalacturonase is unknown, and Athanasiou et al (2003) suggest that it might belong to a small multigene family of pollen polygalacturonases.

In this paper, we explore in more detail the findings of Athanasiou and Shore (1997) and Athanasiou et al (2003), by using immunoblotting with polyclonal antibodies made against the short-specific pollen and style polygalacturonases. If these polygalacturonases are involved in distyly, then we would expect them to occur in shortstyled plants of all distylous species of Turnera, and more widely within the Turneraceae, since it would seem unlikely that distyly and its incompatibility system would have evolved more than once within the genus and/or family. We survey additional species in the genus Turnera and extend the analysis to a Piriqueta species, a member of another large distylous genus in the Turneraceae. We also investigate the presence of these polygalacturonases in a self-compatible long-homostyle 
somatic mutant that arose on a branch of a short-styled plant. We would expect the mutant to lack the style polygalacturonase, but to possess the pollen polygalacturonase.

While distyly is widespread within the Turneraceae, self-compatible homostylous species also occur (Barrett and Shore, 1987). Homostylous species within the series Turnera (=Canaligerae Urb.), appear to be long homostyles (having long styles and stamens). The homostylous Turnera species investigated are self-compatible, and exhibit inheritance patterns and incompatibility responses consistent with a recombinant origin of homostyly (Shore and Barrett, 1985; Barrett and Shore, 1987; Tamari et al, 2001), as occurs in Primula (Ernst, 1955; Dowrick, 1956; Richards, 1997). If these self-compatible species, within the Turneraceae, are long homostyles that have arisen through recombination within the distyly locus, we would expect their styles to lack the shortspecific style polygalacturonase, but their pollen should possess the short-specific pollen polygalacturonase. We test this hypothesis by investigating the distribution of the polygalacturonases in six homostylous species.

\section{Materials and methods}

We investigated the presence/absence of the polygalacturonases in the styles and pollen of 19 populations in 12 species of Turnera, and two species of Piriqueta. We used SDS-polyacrylamide gel electrophoresis (SDS-PAGE) and immunoblotting to study the presence/absence of the style polygalacturonase. Isoelectric focusing (IEF) gel electrophoresis and immunoblotting were used to investigate the morph-specific pollen polygalacturonase. All procedures were carried out at room temperature, unless otherwise indicated.

\section{Style polygalacturonase}

Crude extracts of styles were subjected to SDS-PAGE (discontinuous gel system, stacking $C=5 \%$, resolving $C=10 \%$, following Hames and Rickwood (1987) with slight modifications). Three styles were ground on ice for each plant, in $20 \mu \mathrm{l}$ of phosphate-buffered saline (PBS, $0.8 \% \mathrm{NaCl}, 0.02 \% \mathrm{KCl}, 0.144 \% \quad \mathrm{Na}_{2} \mathrm{HPO}_{4}$ and $0.024 \%$ $\mathrm{KH}_{2} \mathrm{PO}_{4} ; \mathrm{pH}=7.4$ ). Extracts were transferred to a microfuge tube containing $5 \mu \mathrm{l}$ of the loading buffer (54\% glycerol (v/v), 8\% SDS (w/v), 25\% $\beta$-mercaptoethanol $(\mathrm{v} / \mathrm{v}), 0.024 \%$ bromophenol blue $(\mathrm{w} / \mathrm{v}))$. Samples were vortexed briefly, heated in boiling water for $3 \mathrm{~min}$, and centrifuged at $13000 \times g$ for $5 \mathrm{~min}$. The supernatant (approx. $20 \mu \mathrm{l}$ of each sample), ladder (precision or kaleidoscope markers, BIO-RAD) and the style fusion protein (as a positive control) were loaded into the gels. As another positive control, on each gel, we ran extracts of styles and pollen of the short-styled plant BRY (T. subulata from Arco Verde, Brazil), from which the style and pollen polygalacturonase genes were sequenced. Production of fusion proteins and antibodies is detailed elsewhere (Athanasiou et al, 2003).

Proteins were stacked at $50 \mathrm{~V}$ and separated at $140 \mathrm{~V}$. The proteins were electrophoretically transferred, in Towbin-buffered saline $(25 \mathrm{mM}$ Tris, $192 \mathrm{mM}$ glycine, $20 \%$ methanol, $\mathrm{pH}=8.3$ using a mini-Trans-Blot cell, $\mathrm{BIO}-\mathrm{RAD})$, to $0.2 \mu \mathrm{m}$ Immuno-blot polyvinylidene difluoride (PVDF) membranes (BIO-RAD), according to the manufacturer's instructions. The transfer was done overnight at $30 \mathrm{~V}$ followed by $100 \mathrm{~V}$ for $1 \mathrm{~h}$, at $4^{\circ} \mathrm{C}$. Immunoblotting was then carried out as described below.

\section{Pollen polygalacturonase}

IEF and immunoblotting were undertaken to investigate the pollen polygalacturonase. IEF Ready Precast Gels (Amersham-Pharmacia Biotech AB, Ampholine ${ }^{\mathrm{TM}}$ PAG plate, $\mathrm{pH} 5.5-8.5, T=4 \%, C=3 \%$ ) were prefocused at $6 \mathrm{~W}$ for $1 \mathrm{~h}$ at $10-12^{\circ} \mathrm{C}$, using $0.4 \mathrm{M}$ HEPES and $1 \mathrm{M}$ $\mathrm{NaOH}$ as the anodal and cathodal buffers, respectively. All the five anthers from each flower were extracted on ice, in $30 \mu \mathrm{l}$ of extraction buffer $\left(0.05 \mathrm{M} \mathrm{NaH} \mathrm{C}_{6} \mathrm{H}_{6} \mathrm{O}_{2}\right.$ titrated with an equal volume of $0.05 \mathrm{M} \mathrm{Na}_{2} \mathrm{HPO}_{4}$ ). Samples were applied using precut wicks of miracloth (CALBIOCHEM). Electrophoretic separation was conducted at $6 \mathrm{~W}$ for $1.5 \mathrm{~h}$. Protein transfer to PVDF membranes was performed electrophoretically in $0.7 \%$ acetic acid overnight at $30 \mathrm{~V}$. Immunoblotting was then carried out (see below).

\section{Immunoblotting}

Immunoblotting was performed following Riggs and Hasenkampf (1991), with a minor modification. Membranes were blocked in Tris-buffered saline (TBST containing $0.05 \%$ Tween $20, \mathrm{pH}=7.5,0.5 \mathrm{~h}$ ), followed by incubation with a 1:2000 dilution of the $1^{\circ}$ antibody $(2 \mathrm{~h})$ in TBST. The $1^{\circ}$ antibodies were raised against both the style and pollen polygalacturonases, as described in Athanasiou et al (2003). After three $10 \mathrm{~min}$ washes with TBST, the membranes were incubated with a 1:10000 dilution of the $2^{\circ}$ antibody (monoclonal goat anti-rabbit antibody conjugated to alkaline phosphatase, Sigma) in TBST ( $1 \mathrm{~h})$. Three more washes with TBST were performed before the membranes were incubated in substrate solution 5-bromo-4-chloro-3-indolyl phosphate/nitro blue tetrazolium (NBP-BCIP, Sigma) at $37^{\circ} \mathrm{C}$ in the dark. All immunoblotting procedures, with the exception of the substrate colorimetric reaction, were carried out with gentle agitation.

\section{Results}

The results of immunoblotting to detect the presence or absence of the style polygalacturonase are unambiguous, showing a complete association between possession of the protein by all short-styled plants of the Turnera species investigated, and its absence in all long-styled plants (Table 1, Figure 1). Immunoblotting revealed a protein band of approximately $35 \mathrm{kDa}$, unique to shortstyled plants. Note that a $120 \mathrm{kDa}$ protein that is neither morph- nor tissue-specific appears using one of two sources of antibody (Figure 1), and provides a convenient internal loading marker (Athanasiou et al, 2003). Combined with the data of Athanasiou and Shore (1997), the results hold for the six species and 12 populations we have investigated. A single short-styled plant of T. weddelliana (Series Salicifoliae Urb.) possessed a protein band of approximately $37 \mathrm{kDa}$. Interestingly, for distylous Piriqueta caroliniana, neither short- nor longstyled plants showed the presence of the style polygalacturonase (Table 1, Figure 1b).

We carried out a parallel investigation for the pollen polygalacturonase of $\mathrm{pI} 6.8$ identified in Athanasiou and Shore (1997) and Athanasiou et al (2003). The pI 6.8 
Table 1 Distribution of the style polygalacturonase (SP) in distylous species using SDS-PAGE immunoblotting

\begin{tabular}{|c|c|c|c|c|c|}
\hline \multirow[t]{2}{*}{ Species } & \multirow[t]{2}{*}{ Chromosome number } & \multicolumn{2}{|l|}{ Short } & \multicolumn{2}{|l|}{ Long } \\
\hline & & \#with SP & $\mathrm{N} \neq$ & \#with SP & $\mathrm{N}$ \\
\hline T. concinna (Conc) & $2 x=10$ & 6 & 6 & 0 & 6 \\
\hline T. grandiflora (Gran) & $2 x=10$ & 16 & 16 & 0 & 17 \\
\hline T. joelii (Joli) & $2 x=10$ & 17 & 17 & 0 & 15 \\
\hline T. krapovickasii (Krpo) & $2 x=10$ & 23 & 23 & 0 & 22 \\
\hline T. scabra (Cosr) & $2 x=10$ & 8 & 8 & 0 & 8 \\
\hline T. scabra (Mrgd) & $2 x=10$ & 5 & 5 & 0 & 5 \\
\hline T. scabra (Nica) & $2 x=10$ & 5 & 5 & 0 & 5 \\
\hline T. scabra (Dor4) & $4 x=20$ & 9 & 9 & 0 & 9 \\
\hline T. scabra (Dor7) & $4 x=20$ & 6 & 6 & 0 & 6 \\
\hline T. subulata $(\mathrm{Subu})^{\mathrm{a}}$ & $2 x=10$ & 15 & 15 & 0 & 16 \\
\hline T. subulata (SL8) & $2 x=10$ & 5 & 5 & 0 & 5 \\
\hline T. subulata (E) & $4 x=20$ & 5 & 5 & 0 & 5 \\
\hline P. caroliniana (Pird) & $2 x=14$ & 0 & 15 & 0 & 15 \\
\hline
\end{tabular}

${ }^{a}$ These are selfed progeny of BRY (see Athanasiou and Shore, 1997). Species (code), chromosome number, number of plants with the style polygalacturonase and sample size $(N)$ are provided for shortand long-styled plants.

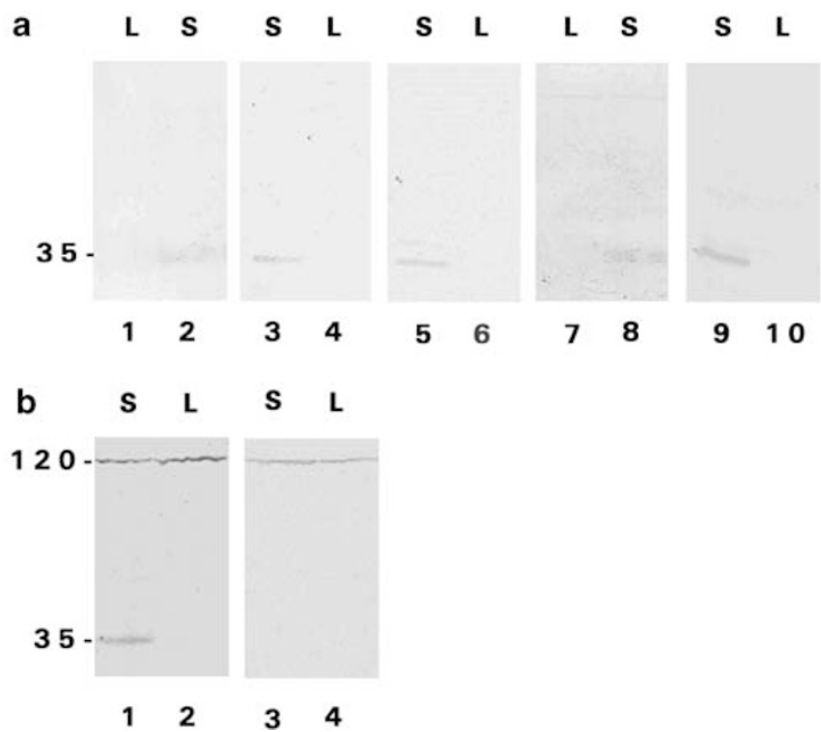

Figure 1 SDS-PAGE immunoblots of style extracts. (a) A $35 \mathrm{kDa}$ polygalacturonase occurs in styles of short-styled plants (S) of five Turnera spp. The polygalacturonase does not occur in long-styled plants (L). Lanes 1, 2: T. concinna; lanes 3, 4: T. grandiflora; lanes 5, 6: T. joelii; lanes 7, 8: T. krapovickasii; lanes 9, 10: T. subulata. (b) A $120 \mathrm{kDa}$ protein also appears in immunoblots using one source of antibody providing an internal marker of protein loading levels. Lane 1: short-styled plant of T. scabra (Nica) possesses the $35 \mathrm{kDa}$ polygalacturonase; lane 2: long-styled plant of T. scabra (Nica) does not have the protein; lanes 3, 4: the protein does not occur in styles of short- or long-styled plants of P. caroliniana.

polygalacturonase does not occur in long-styled plants (with a single exception where a band is present at pI 6.8 for a long-styled plant of T. subulata), and occurs in all short-styled plants of T. concinna and T. subulata, and most short-styled plants of T. scabra (Table 2). The pI 6.8 polygalacturonase does not occur in short- or long-styled plants of T. grandiflora, T. joelii, or P. caroliniana, nor do
Table 2 Distribution of the $\mathrm{pI} 6.8$ pollen polygalacturonase (PP) in distylous species using IEF-PAGE immunoblotting

\begin{tabular}{|c|c|c|c|c|c|}
\hline \multirow[t]{2}{*}{ Species } & \multirow[t]{2}{*}{ Chromosome number } & \multicolumn{2}{|l|}{ Short } & \multicolumn{2}{|c|}{ Long } \\
\hline & & \#with PP & $\mathrm{N}$ & vith $P$ & $\mathrm{~N}$ \\
\hline T. concinna (Conc) & $2 x=10$ & 5 & 5 & 0 & 5 \\
\hline T. grandiflora (Gran) & $2 x=10$ & 0 & 22 & 0 & 21 \\
\hline T. joelii (Joli) & $2 x=10$ & 0 & 16 & 0 & 16 \\
\hline T. krapovickasii (Krpo) & $2 x=10$ & 7 & 16 & 0 & 16 \\
\hline T. scabra (Cosr) & $2 x=10$ & 5 & 5 & 0 & 5 \\
\hline T. scabra (Mrgd) & $2 x=10$ & 3 & 6 & 0 & 4 \\
\hline T. scabra (Nica) & $2 x=10$ & 5 & 6 & 0 & 6 \\
\hline T. scabra (Dor4) & $4 x=20$ & 5 & 5 & 0 & 5 \\
\hline T. scabra (Dor7) & $4 x=20$ & 5 & 5 & 0 & 6 \\
\hline T. subulata (Subu)a & $2 x=10$ & 30 & 30 & 1 & 26 \\
\hline T. subulata (SL8) & $2 x=10$ & 5 & 5 & 0 & 5 \\
\hline T. subulata (E) & $4 x=20$ & 5 & 5 & 0 & 5 \\
\hline P. caroliniana (Pird) & $2 x=14$ & 0 & 23 & 0 & 26 \\
\hline
\end{tabular}

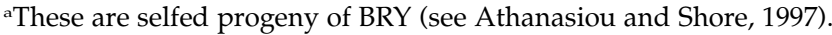
Species (code), chromosome number, number of plants with the pollen polygalacturonase and sample size $(N)$ are provided for short- and long-styled plants.

these species show any evidence of a morph-specific pollen polygalacturonase at any other pI (Figure 2a). There is a polymorphism for the presence/absence of the pI 6.8 polygalacturonase among short-styled plants of T. krapovickasii, as well as some variation in staining intensity (Table 2, Figure 2b).

In August 1998, we discovered a self-compatible somatic mutant homostyle (having long styles and long stamens) on an otherwise self-incompatible short-styled plant. The inheritance of this mutation will be described elsewhere (F Tamari and JS Shore, unpublished results). The mutant shoot arose on a hybrid we had made between two distylous diploid species, T. subulata and T. krapovickasii. We have made numerous replicate cuttings of the mutant (homostyle) and nonmutant (short-styled) shoots, and have continued to propagate these in the glasshouse. We ran extracts of styles of the non-mutant short-styled plant and the mutant homostyle on SDS-PAGE, and used immunoblotting to detect the style protein (Figure 3a). Styles of the short-styled plant possess the $35 \mathrm{kDa}$ polygalacturonase, but styles of the mutant homostyle do not. Pollen of both the homostyle and short-styled plant both possess the pI 6.8 pollen polygalacturonase.

\section{Homostylous species}

Self-compatible long-homostyled species of Turnera and one of Piriqueta were investigated for the presence of both polygalacturonases (Table 3). None of these six homostylous species possess the style polygalacturonase (Table 3, Figure $3 \mathrm{~b}$ ). The pI 6.8 pollen polygalacturonase occurs in the pollen of some homostylous species, but not in others (Table 3). For example, the polygalacturonase was detected in all the four plants of T. velutina, but not in T. aurelii (Figure 3c). T. orientalis has a pollen polygalacturonase that appears to be slightly less than $\mathrm{pI}$ 6.8 (Figure 3c), and it is not clear if this is the same polygalacturonase that occurs in short-styled plants. Numerous other polygalacturonase bands appear in the 
a

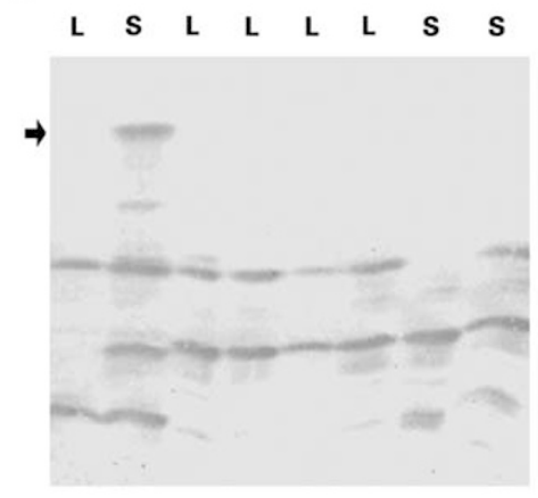

1

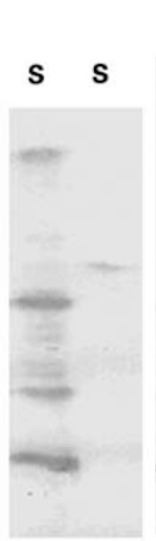

$9 \quad 10$

\section{L $\mathbf{S}$}

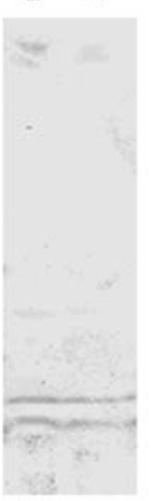

1112

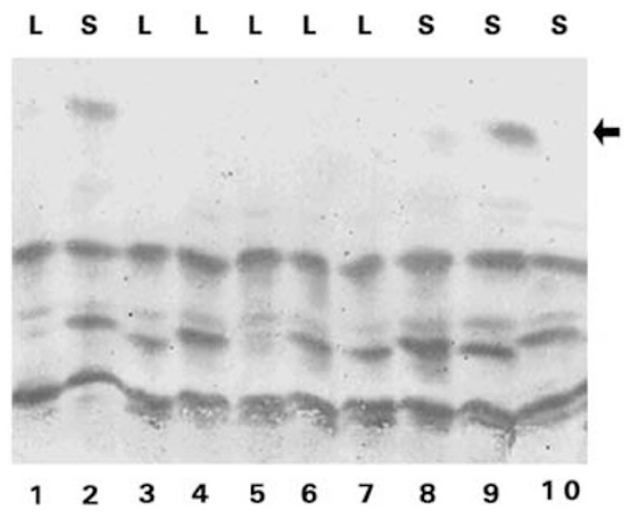

Figure 2 IEF-PAGE immunoblots of pollen extracts. (a) Presence of the $\mathrm{pI} 6.8$ polygalacturonase (see arrow) in the pollen of short-styled plants (S) of T. subulata and its absence from long-styled plants (L) and from both morphs of three other species. Lanes 1, 2 and 9: T. subulata (Subu); lanes 3-8: T. joelii; lane 10: P. caroliniana; lanes 11, 12: T. grandiflora. For the Turnera species, a number of pollen polygalacturonases are common to both morphs. P. caroliniana shows only a single band. (b) The pI 6.8 polygalacturonase (arrow) is polymorphic in short-styled plants (S) of T. krapovickasii (Krpo) and absent from longs (L). Lanes 1, 2: T. subulata (Subu) as a control; lanes 3-10: T. krapovickasii.

homostylous species, although homostylous P. cistoides shows only a single band.

\section{Discussion}

Our results confirm the specificity of the $35 \mathrm{kDa}$ polygalacturonase to styles of short-styled plants of all the six species of Turnera we have been able to sample. Recent immunocytochemistry analyses show that the polygalacturonase localizes in the style-transmitting tissue (Athanasiou et al, 2003; Khosravi et al, 2003). All of these species are in series Turnera (=Canaligerae Urb.) of the genus, and have a base chromosome number of $x=5$, while most other series and genera have a base number of $x=7$ (Barrett and Shore, 1987; Fernandez, 1987). Outside this series of the genus, we have only been able to examine one short-styled plant of $T$. weddelliana (series Salicifoliae Urb.) using immunoblotting, and it possessed a protein band having a molecular mass of approximately $37 \mathrm{kDa}$. Significantly, a mutant homostyle does

a $\quad$ H S S

$120-$

35 .
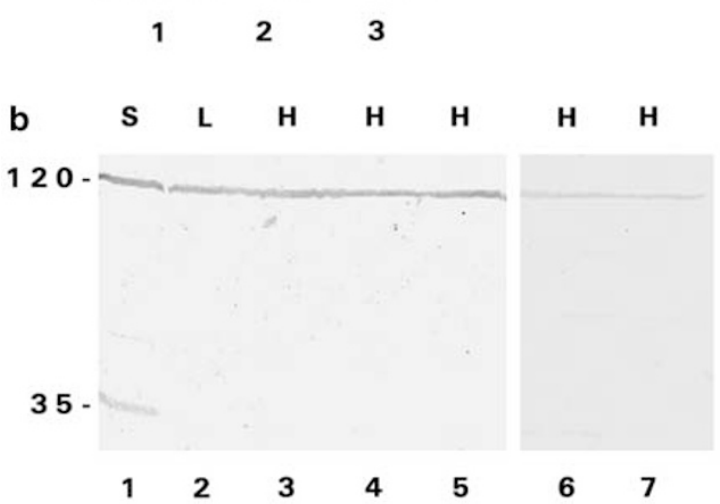

C

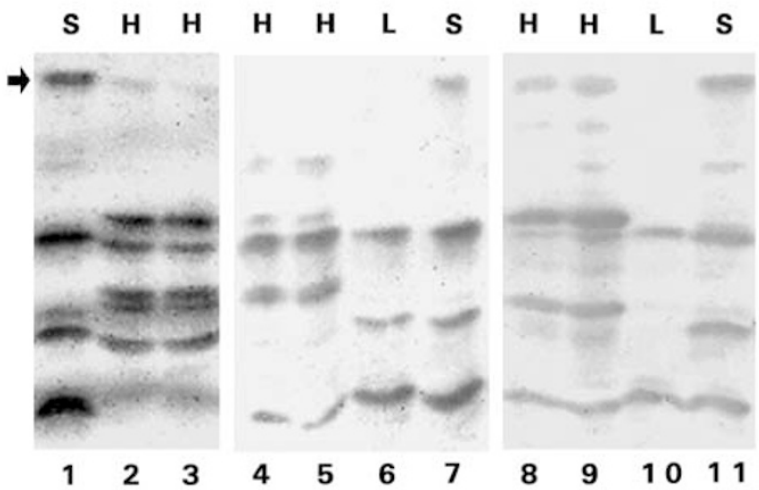

Figure 3 Immunoblots for a somatic mutant homostyle and homostylous species. (a) SDS-PAGE immunoblots of style extracts showing the presence of the $35 \mathrm{kDa}$ polygalacturonase for styles of short-styled plants (S), but not for the somatic mutant homostyle (H). Lane 1: T. subulata $\times$ krapovickasii somatic mutant homostyle (Mhomo H); lane 2: T. subulata $\times$ krapovickasii nonmutant (Mhomo S); lane 3: T. subulata (Subu) as a control. (b) SDS-PAGE immunoblots of style extracts for homostylous species. The $35 \mathrm{kDa}$ polygalacturonase is present in styles of the control short-styled plant (S), but not in the long-styled (L) or any of the homostylous plants $(\mathrm{H})$. The nonspecific $120 \mathrm{kDa}$ band is present in all styles. Lanes 1, 2: T. subulata (Subu) as a control; lanes 3-5: T. ulmifolia (Ulm3); lanes 6, 7: T. aurelii. (c) IEF-PAGE immunoblots of pollen extracts for three homostylous species. The $\mathrm{pI} 6.8$ polygalacturonase (arrow) occurs in the control lanes of short-styled T. subulata (S) and for homostylous plants $(\mathrm{H})$ of $T$. velutina and possibly for T. orientalis, although in the latter species the $\mathrm{pI}$ of the band is somewhat less than 6.8. Lanes 1, 6, 7, 10, 11: T. subulata (Subu) as a control; lanes 2, 3: T. orientalis; lanes 4, 5: T. aurelii; lanes 8, 9: T. velutina.

not possess the style polygalacturonase, while the shortstyled plant that gave rise to it does (Figure 3a). These data, coupled with those in Athanasiou and Shore (1997) and Athanasiou et al (2003) demonstrating its localization 
Table 3 Distribution of the style (SP) and pollen pI 6.8 (PP) polygalacturonase in homostylous species using SDS-PAGE immunoblotting

\begin{tabular}{|c|c|c|c|c|c|}
\hline \multirow[t]{2}{*}{ Species } & \multirow[t]{2}{*}{ Chromosome number } & \multicolumn{2}{|l|}{ Style } & \multicolumn{2}{|l|}{ Pollen } \\
\hline & & \#with SP & $\mathrm{N}$ & \#with PP & \\
\hline T. orientalis (Orie) & $2 n=30$ & 0 & 5 & $5^{\mathrm{a}}$ & \\
\hline T. ulmifolia (Ulm3) & $2 n=30$ & 0 & 16 & 4 & \\
\hline T. ulmifolia (Ulm33) & $2 n=30$ & 0 & 15 & $15^{\mathrm{a}}$ & \\
\hline T. velutina (Velu) & $2 n=30$ & 0 & 4 & 4 & \\
\hline T. aurelii (Ar1) & $2 n=40$ & 0 & 15 & 3 & \\
\hline T. aurelii (Ar2) & $2 n=40$ & 0 & 15 & 5 & \\
\hline T. cuneiformis (Cune) & $2 n=40$ & 0 & 13 & 5 & \\
\hline P. cistoides (Pirh) & $2 n=14$ & 0 & 20 & 0 & \\
\hline
\end{tabular}

${ }^{a} \mathrm{pI}$ of protein slightly less than 6.8 .

Species (code), chromosome number, number of plants with the style polygalacturonase and sample size $(N)$ are provided.

in the style-transmitting tissue, provide strong evidence that the style polygalacturonase is involved in the distylous polymorphism, although its role in the breeding system is unknown.

While no phylogenetic analysis of breeding system variation within the Turneraceae has been undertaken, given the widespread occurrence of distyly within the family, it seems likely that distyly has had a single origin. If so, we might expect morph-specific proteins involved in distyly and the associated incompatibility system, to appear in all distylous species in the family. For the only species outside the genus Turnera that we have investigated, plants of distylous Piriqueta caroliniana do not possess the style polygalacturonase, based upon our immunoblotting experiments. Three possible explanations for this finding are as follows: (1) the polyclonal antibodies to the style polygalacturonase were made against a portion of a style polygalacturonase fusion protein obtained from T. subulata (Athanasiou et al, 2003). It is possible that a short-specific style polygalacturonase does occur in $P$. caroliniana, but that it has diverged sufficiently so that the necessary epitopes for antibody detection are absent. (2) The style polygalacturonase may not be necessary for the functioning of distyly, but perhaps acts as an accessory protein involved in some aspect of the pollination process of short-styled plants of Turnera spp. (3) Some aspect of the distylous breeding system has arisen independently in Turnera and Piriqueta (eg the self-incompatibility system). A wider analysis of species within the Turneraceae, using Northerns blots and/or rtPCR to detect style polygalacturonase mRNA, might allow us to distinguish among some of these hypotheses.

Investigation of the pollen polygalacturonase casts doubt on its involvement in distyly. We show that the pI 6.8 polygalacturonase detected by Athanasiou and Shore (1997) and Athanasiou et al (2003) is not present in a number of distylous species. This suggests that the polygalacturonase might have been linked to and is in linkage disequilibrium with the $S$ allele of distyly, at least in T. concinna, T. subulata and T. scabra. The absence of the pI 6.8 polygalacturonase from $T$. joelii, T. grandiflora and some short-styled plants of T. krapovickasii cast doubt on its involvement in distyly, despite the initial association reported by Athanasiou and Shore (1997).
The distribution of the pollen polygalacturonase varies within and among the homostylous species investigated. Furthermore, it is no longer clear that the pollen polygalacturonase provides a marker for exploring the origins of homostyly, as it does not appear to be a component of distyly (the putative ancestral breeding system), as we note above. All plants of allohexaploid T. velutina possess the pollen polygalacturonase, while none of the plants of allooctaploid T. aurelii do. Given that the homostyles are allohexaploids or allooctaploids (Fernandez, 1987; Fernandez and Arbo, 2000), the occurrence of the pollen polygalacturonase will depend upon the progenitor species that have given rise to them, and whether the polygalacturonase occurred in pollen of those species.

In marked contrast, none of the six homostylous species we studied possessed the style polygalacturonase based upon immunoblotting of style extracts. Recent immunocytochemical analyses support these results (Khosravi et al, 2003). This finding is consistent with the hypothesis that the homostyles have arisen via recombination within a distyly supergene, as in Primula spp (Ernst, 1955; Dowrick, 1956), and that their styles are similar to those of long-styled plants. In Turnera, styles of the homostylous species usually inhibit pollen from long-styled plants, but allow growth of pollen tubes from short-styled plants through their styles (Barrett and Shore, 1987; Tamari et al, 2001). We do not know whether the homostylous species of Turnera have arisen independently, and phylogenetic studies to explore this question are currently underway (S Truyens, MM Arbo and JS Shore, unpublished results). While hybrids among hexaploid T. ulmifolia, T. orientalis and T. velutina are completely sterile, suggesting independent origins (Barrett and Shore, 1987), cytogenetic analyses indicate that $T$. orientalis shares three genomes in common with octaploid T. cuneiformis and T. aurelii (Fernandez and Arbo, 2000). Thus, it is not clear whether the absence of the style polygalacturonase from the homostylous species represents five independent events or just one. Phylogenetic studies of the Turneraceae will aid in addressing this question.

\section{Acknowledgements}

We thank MM Arbo for kindly providing seeds from a number of plant species used in this study, and Davood Khosravi for technical expertise and advice. This work was funded by an NSERC grant to JSS.

\section{References}

Athanasiou A, Khosravi D, Tamari F, Shore JS (2003). Characterization and localization of short-specific polygalacturonase in distylous Turnera subulata (Turneraceae). Am J Bot 90: $675-682$.

Athanasiou A, Shore JS (1997). Morph-specific proteins in pollen and styles of distylous Turnera (Turneraceae). Genetics 146: 669-679.

Barrett SCH, Shore JS (1987). Variation and evolution of breeding systems in the Turnera ulmifoliaL. complex (Turneraceae). Evolution 41: 340-354.

Dowrick VPJ (1956). Heterostyly and homostyly in Primula obconica. Heredity 10: 219-236.

Ernst A (1955). Self-fertility in monomorphic Primulas. Genetica 27: $91-148$. 
Fernandez A (1987). Estudios cromosomicos en Turnera y Piriqueta (Turneraceae). Bondplandia 6: 1-21.

Fernandez A, Arbo MM (2000). Cytogenetic relationships between Turnera aurelii, T. cuneiformis $(2 n=8 x=40)$ and T. orientalis $(2 n=6 x=30)$. Cytologia 65 : $97-102$.

Golynskaya EL, Bashnikova NV, Tomchuk NN (1976). Phytohaemagglutinins of the pistil in Primula as possible proteins of generative incompatibility. Sov Plant Physiol 23: 169-176.

Hames BD, Rickwood D (1987). Gel Electrophoresis of Proteins: A Practical Approach. IRL Press: Washington, DC.

Khosravi D, Joulaie R, Shore JS (2003). Immunocytochemical distribution of polygalacturonase and pectins in styles of distylous and homostylous Turneraceae. Sex Plant Reprod 16: 179-190.

Richards AJ (1997). Plant Breeding Systems. 2nd edn. Chapman \& Hall: London.
Riggs CD, Hasenkampf CA (1991). Antibodies directed against a meiosis-specific, chromatin-associated protein identify conserved meiotic epitopes. Chromosoma 101: 92-98.

Shivanna KR, Heslop-Harrison J, Heslop-Harrison Y (1981) Heterostyly in Primula 2. Sites of pollen inhibition, and effects of pistil constituents on compatible and incompatible pollen-tube growth. Protoplasma 107: 319-337.

Shore JS, Barrett SCH (1985). The genetics of distyly and homostyly in Turnera ulmifolia L. (Turneraceae). Heredity 55: 167-174.

Tamari F, Athanasiou A, Shore JS (2001). Pollen tube growth and inhibition in distylous and homostylous Turnera and Piriqueta (Turneraceae). Can J Bot 79: 578-591.

Wong KC, Watanabe M, Hinata K (1994). Protein profiles in pin and thrum floral organs of distylous Averrhoa carambola L. Sexual Plant Reprod 7: 107-115. 